\title{
Erratum to: The Measurement of Multidimensional Gender Inequality: Continuing the Debate
}

\author{
Iñaki Permanyer
}

Published online: 12 March 2010

(C) Springer Science+Business Media B.V. 2010

\section{Erratum to: Soc Indic Res (2010) 95:181-198 DOI 10.1007/s11205-009-9463-4}

In the acknowledgments section the author forgot to mention one of the funding entities that supported the research. The Acknowledgments should read:

Acknowledgments I would like to thank Lourdes Beneria for all comments and support on the successive versions of this paper. Joint support from the Fulbright-Generalitat de Catalunya fellowship and the Spanish Ministry of Science and Education R\&D project "Familias reconstituidas y equidad de género: nuevas paradojas" (Ref. CSO2008-00654) is gratefully acknowledged.

The online version of the original article can be found under doi:10.1007/s11205-009-9463-4.

I. Permanyer $(\bowtie)$

Department of City and Regional Planning, Cornell University, West Sibley Hall,

Ithaca, NY 14853, USA

e-mail: ip52@cornell.edu 